\title{
Significance of microfinance institutions in rural development of India
}

\author{
Rajesh K. Yadav \\ Department of Management, RKDF College of Engineering, Bhopal, M.P., India \\ E-mail address: drrajeshkyadav@yahoo.com
}

\begin{abstract}
Micro finance is to supply micro credit to people living in utter poverty and has no reach to the conservative and formal financial products. It is an aid to engage them in productive activities and grow their tiny businesses. Micro finance focused on availing the credit in a standard manner. Micro financial schemes plays vital role in increasing women's participation in economic activities and decision making. In this research paper an effort is made to investigate the role of microfinance in rural development especially through Micro financial schemes. This study is an empirical study which aims to find out the role and responsibilities of microfinance in rural development. Our experience while doing this study suggests that microfinance provides key lessons for development in terms of what mechanism and best practices should be adopted and how to make small change that creates a big difference. It is concluded that poor people in rural areas especially in under developing countries, are in immense need of credits so microfinance programs must make available this credit needs and motivate the poor people to increase their standard of living.
\end{abstract}

Keywords: Microfinance; Rural development; Economy; Financial Services etc.

\section{INTRODUCTION}

With a huge segment of the world's underprivileged, India is likely to have a large possible demand for microfinance. For this reason, it makes sense to consider the changing face of microfinance for rural development in India. Microfinance refers offering exceptionally small loans to very poor families with the purpose of engaging them into productive activities. Micro finance bank is an institution that extends small loan or micro finance, to applicant who typically belongs to the lowest group of society. Loans are extended to borrower to allow them to initiate a business, repair their homes and improve the general living condition of their families and the community. Microfinance is considered as a tool for socio-economic development, and can be clearly differentiated from donations.

When it comes to rural development, with the growth of the credit infrastructure, credit flow to the poor and especially to poor women, remained near to the ground. As a result National Bank for Agriculture and Rural Development (NABARD) was set up with the objective of framing appropriate policy for rural credit, provision of technical assistance backed liquidity support to banks, supervision of rural credit institutions and other development initiatives. After a time it was experienced that the existing banking policies, systems and procedures, and deposit \& loan products were possibly not well matched to meet the instant 
needs of the poor. It was experienced that the poor desired improved access to these services and products, more willingly than cheap financed credit. If a person observes an institution to be unfriendly or uncaring to them, they hesitate to move toward it. Thus a requirement has been experienced for alternative policies, systems and procedures, savings and loan products, other matching services, and new delivery mechanisms, which would fulfill the requirements of the poorest, especially of the women members of such families. This has given beginning to an increasing emphasis on Microfinance for improving the access to credit for the poor. A large number of NGOs have started their own micro finance programs in an attempt to develop the people in their respective areas. Micro credit has become a major tool of development.

The most current succession in this area is savings and credit groups or Self Help Groups (SHGs) as they are known in India, as well as a variety of specialized Micro Finance Institutions (MFIs). To assist and encourage the activities of these groups, significant institutional structures have emerged. A major portion of such support in India has come from non-profit NGOs. These organizations originally initiated the concept of Micro Finance and continue to work towards the delivery of Micro Finance projects in India especially for rural development $[2,7,8,14-17]$.

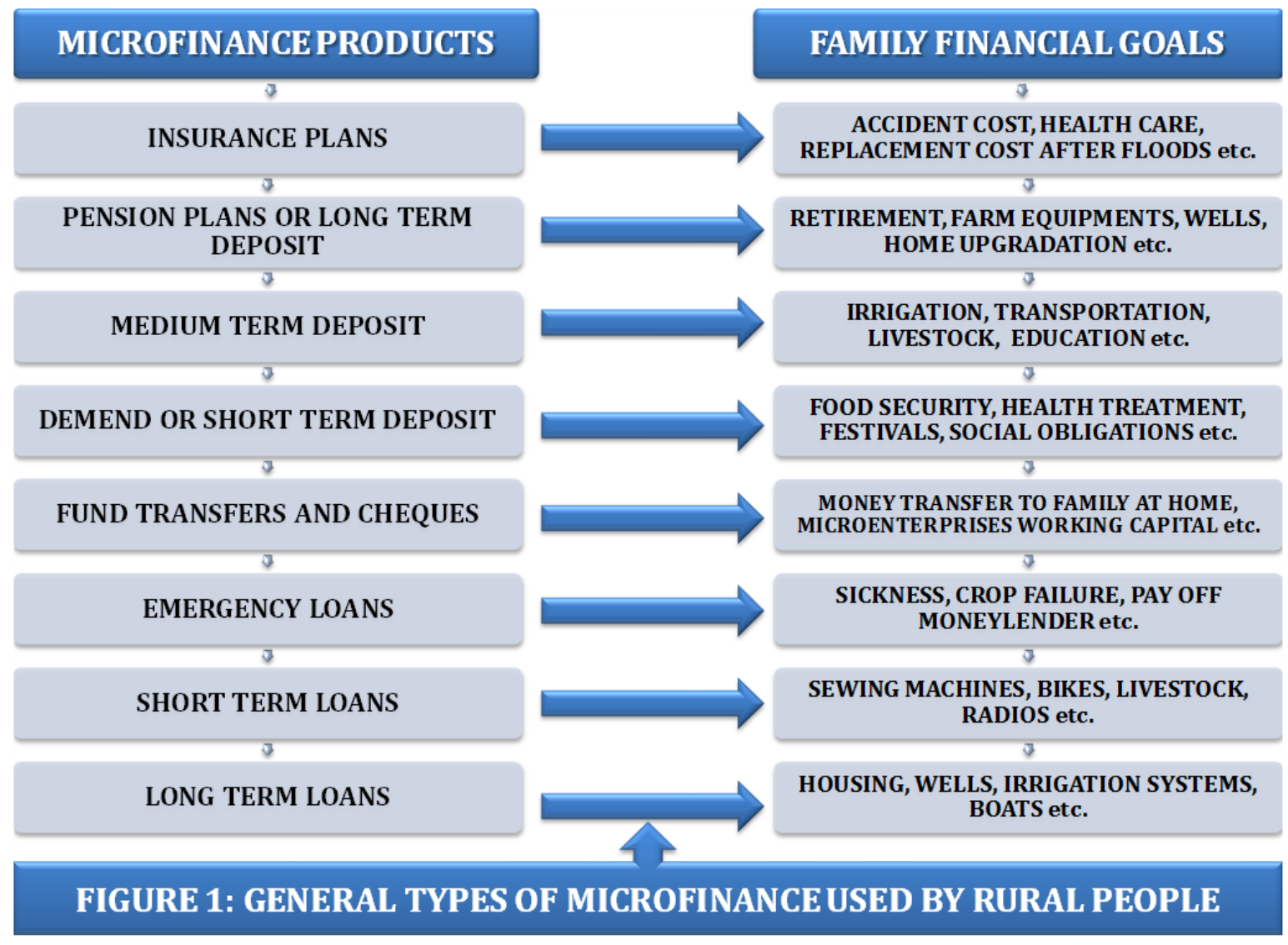

\section{EXISTENCE OF MICRO FINANCE IN INDIA}

The term microfinance came into existence in 1970s when organizations, such as Grameen Bank of Bangladesh with the microfinance pioneer Muhammad Yunus, were starting and shaping the modern industry of micro financing. Even Microfinance in India can map out its origins back to the early 1970s when the Self Employed Women's Association ("SEWA") of the state of Gujarat formed an urban cooperative bank, called the Shri Mahila SEWA Sahakari Bank, with the objective of providing banking services to poor women employed in 
the unorganized sector in Ahmadabad City, Gujarat. The microfinance sector went on to evolve in the 1980s around the concept of SHGs, informal bodies that would provide their clients with much-needed savings and credit services.

Due to large size and population of around 1000 million, India's GDP ranks among the top 20 economies of the world. However, around 400 million people or about 60 million households, are living under the poverty line. It is further predictable that of these households, only about 20 percent have access to credit from the formal sector. As well, the segment of the rural population has no good access to the recognized financial intermediary services, including savings services. Credit on rational terms to the poor can bring about a significant fall in poverty. Hence micro credit assumes significance in the Indian context. With about 60 million households below or just above the strictly defined poverty line and with more than 80 percent unable to access credit at reasonable rates, it is obvious that there are certain issues and problems, which have banned the reach of micro finance to the needy. With globalization and liberalization of the economy, opportunities for the unskilled and the illiterate people are not increasing fast enough, as compared to the rest of the economy. In this context, the institutions involved in micro finance have a significant role in reducing inequality and contribution in rural development for overall growth $[4,6,12]$.

\section{MICROFINANACE AND POVERTY REDUCTION FOR RURAL DEVELOPMENT IN INDIA}

India consists over a quarter of its population below to poverty line. The World Bank reports that India is a home around some 260 to 290 million poor, numbers that rise to around 390 million if poverty is measured by the international standard of those living on less than 1US\$ dollar a day. Almost half of India's poor, more or less 133 million, are found in three states: Uttar Pradesh, Bihar, and Madhya Pradesh. Rural area in India is the home of three quarters of India's poor which is supported by the increasing urban and rural disparities. The Indian government's poverty reduction strategy focuses on infrastructure, social development (especially education and health), and rural livelihoods. The improvement of rural livelihoods is the aspect of poverty reduction that Microfinance Institutions concentrate on. Most poor people manage resources to develop their enterprises and their home over a time. Financial services could enable the poor to force their initiative, accelerating the process of assembling incomes, assets and economic safety.

Traditional finance institutions rarely lend money to serve the needs of low-income families and women-headed households. However, the income of many self employed households is not stable, regardless of its size. A large number of small loans are needed to serve the poor, but lenders prefer dealing with large loans in small numbers to minimize administration costs. They also look for guarantee which many low-income households do not have in hand. Over the last ten years, however, successful experiences in providing finance to small entrepreneur and producers demonstrate that poor people, when given access to responsive and timely financial services at market rates, pay back their loans and use the profits to increase their income and assets. This is not shocking since the only realistic alternative for them is to borrow the money from informal market. Community banks, NGOs and credit groups around the world have shown that these microenterprise loans can be profitable for borrowers and for the lenders, making microfinance one of the most effective poverty reducing strategies $[4,8,10]$. 


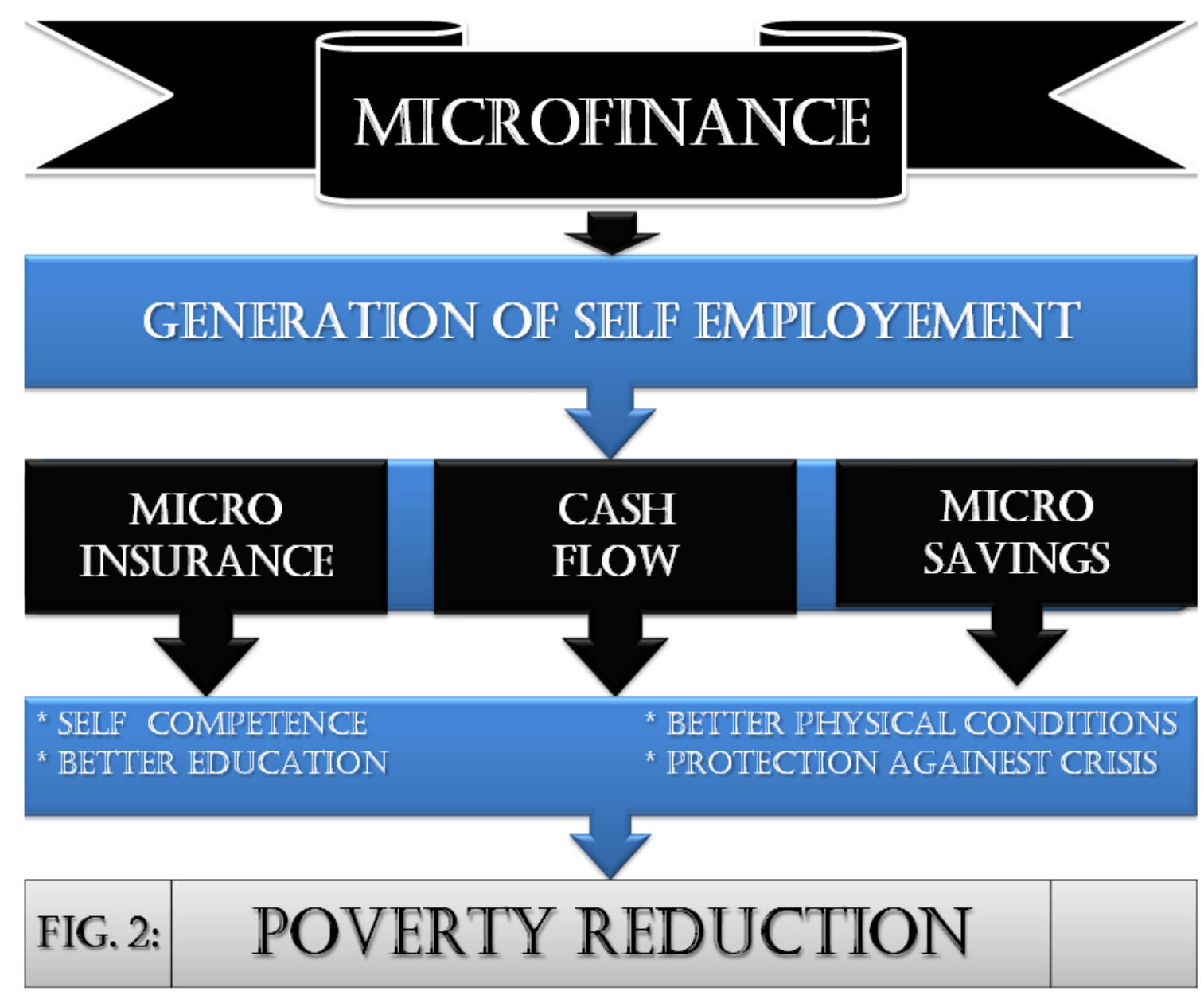

\section{MICROFINANCE AND SELF HELP GROUPS (SGHS) FOR RURAL DEVELPOMENT}

There are two common approaches of Micro Finance India - The Self help groups method and the Grameen system. An SHG is an unofficial group of approximately 10-20 members. The members of the SHG are joined for the specific purpose of facilitating saving and credit services for its members. This is made possible through members pooling their resources to create a common fund. The process and social involvement of SHGs are intended to be instruments of empowerment, building the capacity of members to eventually conduct and manage SHGs for themselves, and enabling them to have greater autonomy in financial decision making as well as wider social participation. SHG meetings are set to take place at regular intervals and at a designated time. Group members are drawn from the same socialeconomic layer and work on the basis of equal participation and contribution from all members. The groups are chaired by one lead member at a time; this role is usually rotated to allow capacity building for all members. Meetings are structured and accurate and up to date records of all financial transactions, group decisions and actions are compiled. Once established, SHGs are encouraged to make links with other SHGs and eventually with financial institutions to allow access to further financial assistance $[3,5,10]$. 


\section{MICROFINANCE AND WOMEN EMPOWERMENT FOR RURAL DEVELOPMENT}

Women are essential part of the society. The role of women in economic activities and decision making is very low. Micro financial schemes plays vital role in increasing women's participation in economic activities and decision making. There has been huge growth of organizations, known as Microfinance Institutions (MFIs) in this field to deal with the micro financial activities. With increasing demand for rural finance, and the shortages of formal sources, the MFIs have tremendous challenges and opportunities in microfinance in India. In India self help groups (SHGs) constitutes of 85-95\% women. The reasons for this is that women are familiar with finances responsibility; making them trustworthy, reliable and prompt savers. Empowerment of women also occupies central place to wide development goals. Women empowerment is critical factor in the eradication of poverty, as the women are the key contributors to the economic and to fighting with poverty through both remunerative and unremunerative work at home, in the community and in the workplace. SHGs have been recognized as one efficient means of empowering women $[3,5,11]$.

\section{CRITICAL ISSUES FOR MICRO FINANCE INSTITUTIONS}

This is not a point of consideration that Micro financial services have capability to offer better services than conventional banking services and carry out the needs of the underprivileged people. The significant factor is that external Micro financial services should join hand to the running system of lending and/or borrowing money in rural areas instead of throwing them out. In this way the poor people especially women who require the fund to run their business and family activities in a well-organized manner will get benefitted more. Some critical issues for microfinance organizations are as follows:

\section{1. Sustainability}

The primary issue is related to sustainability. It has been reported in much news that the Micro financial institutions are comparatively costlier in terms of delivery of financial services. This is partially explained by the fact that the cost of supervision of credit is high, while the loan quantity and loan volume is low. Therefore it is necessary for MFIs to develop strategies for increasing the range and volume of their financial services.

\section{2. Lack of Capital}

The next part of concern for MFIs, which is on the expansion path, is that they face a scarcity of owned funds. This is a critical constraint in their being able to scale up. Many of the MFIs are socially oriented institutions and do not have adequate access to financial capital. As a result they have high debt equity ratios.

\section{3. Borrowings}

In comparison with earlier years, MFIs are now finding it relatively easier to raise loan funds from banks. This change came after the year 2000, when RBI allowed banks to lend to MFIs and treat such lending as part of their priority sector funding obligations. Private sector banks have designed innovative products such as the Bank Partnership Model to fund MFIs and have started viewing the sector as a good business proposition. But banks need to be most 
careful when they feel most confident about MFIs. Bank should find the right technologies to assess the risk of funding MFIs.

\section{4. Capacity of MFIs}

It is now accepted that MFIs has both social and commercial dimensions. Since the sustainability of MFIs and their clients complement each other, it follows that building up the capacities of the MFIs and their primary stakeholders. These are preconditions for the successful delivery of flexible, client responsive and innovative microfinance services to the poor $[1,9,3]$.

\section{CONCLUSION}

The MFI is leaving enormous economic and social impact. Microfinance provide both savings and loan facilities An MFI is likely to provide the much needed funds to the potential entrepreneurs of the rural India. Also it is anticipated that the people would become socially more advanced as they come into touch with the outside world. In order to be sustainable, microfinance lending should be fixed on market principles because large scale lending cannot be completed through financial support.

A core conclusion of this paper is that microfinance can contribute into solving the problem of insufficient housing and rural services as an integral part of poverty alleviation programs and empower women to play a vital role in the society. Eventually it would be ideal to improve the creditworthiness of the poor and to make them more bankable to financial institutions and allow them to meet the criteria for long-term credit from the formal sector. Microfinance institutions have a lot to contribute to this by building financial discipline and educating borrowers about compensation requirements.

\section{References}

[1] Bhatt Nitin, Tang Shui (2001): "Delivering Microfinance in Developing Countries: Controversies and Policy Perspectives Policy Studies”, Policy Studies Journal, 29(2); 3-9.

[2] Brau, James C. Woller, Gary M. (2004): "Microfinance a comprehensive review of the existing literature", Journal of Entrepreneurial Finance, 9(1); 1-26.

[3] Chaves Rodrigo A., Claudio Gonzalez-Vega (1996): 'The Design of Successful Rural Financial Intermediaries: Evidence from Indonesia", World Development, 24(1); 65-78.

[4] Dichter Thomas W. (1996): "Questioning the Future of NGOs in Microfinance", Journal of International Development, 8(2); 259-269.

[5] Havers M. (1996): "Financial sustainability in savings and credit programs", Journals of Economics, 6(2); 144-150.

[6] Iqubal Farukh (1988): "The Determinants of Money Lender Interest Rates: Evidence from Rural India", The Journal of Development Studies, 3; 364-378.

[7] James C. Brau, Gary M. Woller (2004): " Microfinance: A Comprehensive Review of the Existing Literature", Journal of Entrepreneurial Finance and Business Ventures, 9(1) 126. 
[8] Kumar Manish, Bohra Narendra, Singh Johari Amar (2010): "Micro finance as an anti poverty vaccine for rural India" International Review of Business and Finance, 2(1); 2935.

[9] McIntosh Craig, Bruce Wydick (2005): "Competition and microfinance", Journal of Development Economics, 78(2); 271-298.

[10]Pitt Mark M., Shahidur R. Khandker (1998): "The Impact of Group-based Credit Programs on Poor Households in Bangladesh: Does the Gender of the Participants Matter?", Journal of Political Economy, 106(5); 958-996.

[11]Rajakutty S. (1997): "Development of Women and Children in Rural Areas: Are we in the right course?", Journal of Rural Development, 16(1); pp. 85-11.

[12]Robert Cull, Asli Demiguc Kunt, Jonathan Morduch (2007): "Financial performance and outreach: A global analysis of leading microbanks", Economic Journal, 3; 107-133.

[13]Robert Cull, Asli Demirguc-Kunt, Jonathan Morduch (2009): "Microfinance Meets the Market", Journal of Economic Perspectives, 23(1); 167-192.

[14]Rajesh K. Yadav, Nishant Dabhade, International Letters of Social and Humanistic Sciences 4 (2013) 49-69.

[15]Rajesh K. Yadav, Nishant Dabhade, International Letters of Social and Humanistic Sciences 7 (2013) 1-22.

[16]Rajesh K. Yadav, Nishant Dabhade, International Letters of Social and Humanistic Sciences 8 (2013) 77-85.

[17]Rajesh K. Yadav, Nishant Dabhade, International Letters of Social and Humanistic Sciences 5 (2014) 44-62. 